\title{
Effect of calcium in brine on salt diffusion and water distribution of Mozzarella cheese during brining
}

\author{
J. Luo, ${ }^{*}$ T. Pan,† H. Y. Guo, $\ddagger$ and F. Z. Ren*1 \\ *Key Laboratory of Functional Dairy, College of Food Science and Nutritional Engineering, China Agricultural University, Beijing 100083, China \\ †Beijing Higher Institution Engineering Research Center of Animal Product, Beijing 100083, China \\ łBeijing Key Laboratory of Nutrition, Health and Food Safety, Beijing 100083, China
}

\section{ABSTRACT}

A soft, pasty, high-moisture surface defect occurs with progressive brining of Mozzarella cheese. Addition of calcium is traditionally used to prevent this defect but the underlying mechanism is not clear. Mozzarella cheese was formed into a cylinder inside brine on its plane surface to ensure semi-infinite, unidirectional mass transfer and placed into brine containing $0,0.1$, or $0.25 \%$ (wt/wt) calcium chloride. To monitor the effect on cheese composition of calcium in brine, we measured calcium and water contents of the cheese during brining. The extent of calcium loss from the cheese decreased significantly with the addition of calcium. Addition of calcium to a final concentration of $0.25 \%$ decreased the loss of calcium from 94.13 to $18.22 \%$ from the outside region of the cheese after $30 \mathrm{~d}$, and the water content of the cheese was decreased from 67.8 to $48.8 \%$. To further elucidate the effect of calcium in brine, the Boltzmann method was used to determine the effective diffusion coefficient value, and low-field nuclear magnetic resonance was used to measure the cheese transversal relaxation time. The migration of calcium interfered with salt diffusion. At the end of brining, the amount of water bound to the protein of the cheese significantly increased. Addition of calcium to a final concentration of $0.25 \%$ diminished the proportion of bound water by $20.96 \%$. In conclusion, addition of calcium hinders the diffusion of sodium and modifies the distribution of water in Mozzarella cheese during brining.

Key words: calcium, salt diffusion, water distribution, Mozzarella cheese

\section{INTRODUCTION}

Mozzarella is a moist, white, Italian curd cheese originally made from water buffalo (Bubalus sp.) milk. Mozzarella is typically salted in brine, which is critical for proper moisture control and contributes directly

Received June 29, 2012

Accepted October 11, 2012.

${ }^{1}$ Corresponding author: renfazheng@263.net to the flavor, textural, and physical characteristics of Mozzarella cheese (Geurts et al., 1974, 1980). During brining, however, a soft rind defect occurs as the cheese develops a soft, moist, fragile surface layer that is difficult to shred (Kindstedt, 1994). Kindstedt et al. (1996) found that the concentration of calcium was significantly lower at the surface compared with the interior of the cheese. They suggested that calcium has a tendency to be leached from the surface of the cheese, solubilizing casein and causing swelling as water is bound to the protein.

The traditional solution to this problem is to add calcium to the brine in the form of $\mathrm{CaCl}_{2}$. At the target calcium concentration, the risk of soft rind defects is minimized (Kindstedt, 1991; Kristensen, 1999). Kristensen (1999) reported that addition of sufficient calcium restores the equilibrium between the soluble and colloidal forms of calcium, thus preventing the protein from binding water. However, it is not clear whether calcium in brine affects salt diffusion in the cheese.

Salt diffusion, which is responsible for mass transport between the cheese and the brine, depends mainly on the composition of the brine (Guinee, 2004). Gerla and Rubiolo (2003) found that when several solutes diffuse simultaneously, in addition to the self-diffusion coefficient, cross-diffusion has to be included to account for the influence of one solute on the flow of another. Floury et al. (2009) used a modeling approach to investigate the transfer of salt and other ionic solutes and found that $\mathrm{Na}^{+}, \mathrm{Cl}^{-}$, and $\mathrm{K}^{+}$are present mostly in the soluble phase and facilitate salt diffusion. However, the mechanism by which calcium in brine affects salt diffusion is not clear. Further investigation is required to determine whether migration of ionic calcium causes synergy of salt diffusion or inhibition of salt diffusion.

The diffusion of salt is linked to changes in the water content of cheese (Payne and Morison, 1999). The distribution of water in Mozzarella is determined by the parallel protein fibers resulting from the stretching process (Kuo et al., 2003) and water undergoes a continuous rearrangement during ripening (McMahon et al., 1999). Kindstedt et al. (1996) reported that leaching 
of calcium induces solubilization of casein, which binds water and swells, causing the soft rind defect. However, no experimental details are available to monitor the hydration of protein during brining. Nuclear magnetic resonance (NMR) relaxometry is concerned with the quantitative determination of the most abundant components in a sample by evaluating decay rates and amplitudes of the NMR signal. Low-field NMR transverse relaxation has been used to quantify the changes in water distribution and mobility (Kuo et al., 2003).

The aim of the present study was to elucidate details of how calcium added to brine affects salt diffusion and reduces the risk of the soft rind defect for Mozzarella cheese. Mozzarella cheese was molded into cylindrical set to allow mathematical modeling of an effective diffusion process. Cheese was stored in brine containing $0,0.1$, or $0.25 \%$ (wt/wt) calcium chloride. The salt effective diffusion coefficient values during brining in different regions of the cheese were determined by the Boltzmann method, and water distribution was determined using low-field NMR spectroscopy.

\section{MATERIALS AND METHODS}

\section{Mozzarella Cheese Making}

Raw cow milk from the SanYuan Dairy Co. (Beijing, China) was pasteurized $\left(63^{\circ} \mathrm{C}\right.$ for $30 \mathrm{~min}$, cooled to $\left.4^{\circ} \mathrm{C}\right)$ and used at a casein:fat ratio of 0.75 (wt/wt). Milk was warmed to $37^{\circ} \mathrm{C}$ and $0.08 \mathrm{~g} / \mathrm{L}$ of starter culture (FDDVS ST-M5, Chr. Hansen, Hørshlom, Denmark) and 28.75 IMCU (international milk clotting units) of chymosin rennet (Stamix 1150, Chr. Hansen) were added. Curd was set and then cut at pH $6.15 \pm 0.2$, left for 5 min, and stirred gently to facilitate syneresis. When the curd $\mathrm{pH}$ reached $5.25 \pm 0.1$, the remaining whey was drained, and the curds were cooked and stretched for 3 min at $70^{\circ} \mathrm{C}$. Duplicate batches of cheese were made.

\section{Experimental Design}

Brining Experiment. Brining experiments were carried out as described previously (Pajonk et al., 2003). After stretching, the cheese curd ( $\mathrm{pH} 5.20 \pm 0.1$ ) was placed into plastic cylinders (length $2.5 \mathrm{~cm}$, diameter $3 \mathrm{~cm}$ ) and covered with food wax on one flat surface. Brine was prepared with food-grade sodium chloride at a concentration of $20 \%$ (wt/vol) in distilled water. Calcium chloride was added to reach $0,0.1$, or $0.25 \%$ (wt/wt), and the $\mathrm{pH}$ was adjusted to 5.18 using acetic acid. The brining containers containing cheese samples were covered with plastic film to prevent surface mass loss and stored for $3 \mathrm{~h}$ at $4^{\circ} \mathrm{C}$. Therefore, the temperature of cheese and brine was $4^{\circ} \mathrm{C}$ during brining. The

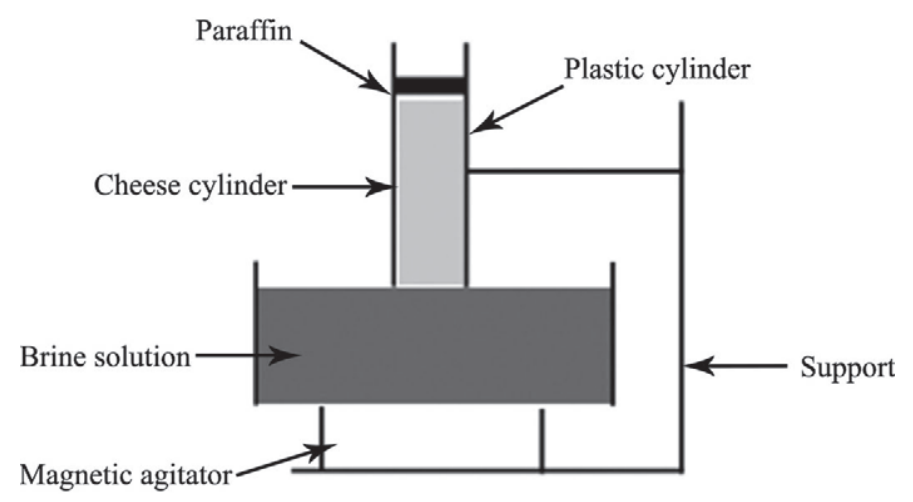

Figure 1. Diagram of the experimental brining device.

experimental brining apparatus is illustrated in Figure 1. Keeping the cheese cylinder inside the brine on its plane surface allowed a unidirectional transfer of ionic sodium and calcium mass. The brine was submitted to continuous slow agitation using a magnetic stirrer.

Sampling. After brining, cheese samples were rinsed with distilled water and the surface was dried on filter paper. Periodically, 2 cylindrical samples of cheese were removed simultaneously to duplicate physicochemical analyses. Cheese samples were cut from the cylinder as 5 -mm-thick slices at 0 to $0.5 \mathrm{~cm}, 1$ to $1.5 \mathrm{~cm}$, and 2 to $2.5 \mathrm{~cm}$ along the length. The usual radius of Mozzarella cheese ball is $\sim 2.5 \mathrm{~cm}$; therefore, the chosen sites sampled the outer, inner, and central regions of the cheese, respectively. To understand the mechanisms of diffusion in cheese for an extended brining period, sampling was conducted at $1,5,9$, and $24 \mathrm{~h}$, and at 7 $(168 \mathrm{~h})$ and $30 \mathrm{~d}(720 \mathrm{~h})$.

\section{Compositional Analysis}

Cheese samples were analyzed for water (ISO-IDF, 1982), fat (Marshall, 1992), and protein (ISO-IDF, 1986) contents. Ionic concentrations were measured by atomic absorption spectrometry (725-ES, Varian, Palo Alto, CA) as described (AOAC International, 2000) and were expressed in milligrams per $100 \mathrm{~g}$ of cheese.

\section{Effective Diffusion Coefficient Values and Low-Field NMR}

The Boltzmann method (Pajonk et al., 2003) was used for determination of the effective diffusion coefficient value. The diffusion coefficient represents the apparent diffusivity of sodium chloride, considering the solid cheese matrix and sodium chloride as the 2 components of the binary diffusion system.

A low-field NMR analyzer (MARAN-22 ultraresonance model with $2 \mathrm{MHz}$ proton resonance frequency, 
Oxford Instruments, Oxford, UK) was used for measurement of cheese transversal relaxation times $\left(\boldsymbol{T}_{\mathbf{2}}\right)$. Components with shorter and longer relaxation times are attributed to protons in less mobile and more mobile fractions of water in cheese, respectively; $\boldsymbol{T}_{21}$ is the fast relaxation component, ascribed to a portion of the water tightly bound to the protein matrix; $\boldsymbol{T}_{\mathbf{2}}$ represents water molecules more loosely associated with the protein (bulk water).

Samples $(2 \times 2 \times 0.5 \mathrm{~cm})$ were taken from each region of the cheese cylinder at set time points and placed into sample tubes $(2.5 \mathrm{~cm}$ in diameter). All measurements were done at $24( \pm 0.5)^{\circ} \mathrm{C}$. Transverse relaxation times were measured with a Carr-Purcell-Meiboom-Gill pulse sequence (Carr and Purcell, 1954), with an interpulse spacing of $80 \mu \mathrm{s} ; 2,048$ points were acquired for each of the 64 scans. Transversal relaxation data were fit to a multi-exponential curve by the low-field NMR toolbox for Matlab (R2001a, Mathworks, MathWorks Inc., Natick, MA), as described previously (Pedersen et al., 2002).

\section{Statistical Analysis}

All measurements were done in duplicate. One-way ANOVA was used to analyze the results, and tests for difference were done with Duncan's multiple range method. Statistically significant difference was set at $P<0.05$, and SPSS software (version 16.0, SPSS Inc., Chicago, IL) was used for all analyses.

\section{RESULTS AND DISCUSSION}

\section{Mozzarella Cheese Composition}

The composition of Mozzarella cheese is given in Table 1; the water content was $56.9 \%$ and fat in DM was $46.3 \%$, which met the Codex standard 208-1999 ( $\leq 60 \%$ water, $\geq 40 \%$ fat; Codex Alimentarius, 2003) for soft cheese in brine.

\section{$\mathrm{Ca}^{2+}$ Concentration Profiles}

Similar to the report of Guerts et al. (1972), the rind of cheese salted in brine without calcium was soft and slippery, whereas that of cheese from brine with calcium was hard and felt dry. Figure 2 shows the range of calcium content in different regions of the cheese and the decrease in the outside region during brining. Calcium content in the rest of the cheese was unchanged during the first $24 \mathrm{~h}$ of brining and decreased thereafter. The slight increase in calcium content in the inside region of the cheese from 5 to $24 \mathrm{~h}$ of brining could be caused by water loss, but the increase was not significant on a dry weight basis. The concentration of calcium in the cheese decreases dramatically because sodium ions chelate casein-bound calcium during brining; therefore, bound calcium becomes soluble in the aqueous phase and diffuses out of the cheese into the brine. In the absence of calcium in the brine, the casein-bound calcium in cheese solubilizes and restores the equilibrium between the soluble and colloidal forms (Kindstedt, 1994; Kristensen, 1999).

The decrease in calcium content in the calcium-free brine was $94.13,65.65$, and $44.16 \%$ in the outside, inner, and central regions of the cheese, respectively. At the end of brining, the calcium content of the outside, inner, and central region of the cheese was $18.92,21.50$, and $31.07 \%$, with $0.1 \%$ calcium chloride in the brine, and $18.22,20.33$, and $1.64 \%$ with $0.25 \%$ calcium chloride in the brine, respectively. These results indicate that addition of calcium restores the chemical equilibrium and prevents more calcium dissolving into the brine.

\section{Water and Sodium Ion Content}

Figure 3 shows that water content decreased from the surface to the center of the cheese and these levels changed during brining. Weight loss was least for the cheese in the calcium-free brine and increased as the calcium content of the brine increased. The water content of the cheese decreased from $57.4 \%$ (initial value) to $48.8,47.1$, and $46.1 \%$ in the central region for cheese brined in $0,0.10$, and $0.25 \%$ calcium, respectively. The decrease in water content results from water diffusing through the cheese matrix to restore an osmotic pressure equilibrium (Guinee and Fox, 1986), which could be related to the final production of cheese with a soft rind. As expected, the water content of the cheese in brine with added calcium was significantly lower than that of the cheese in calcium-free brine; the water content of cheese in calcium-free brine peaked at the end of brining. The water content decreased from 67.8 to 56.7 and $48.8 \%$ in the outside region for cheese brined in

Table 1. Composition of Mozzarella cheese before brine salting

\begin{tabular}{lccc}
\hline & \multicolumn{2}{c}{ Composition $^{1}$} & \\
\cline { 2 - 3 } Item & Mean & SD & $\begin{array}{c}\text { Codex } \\
\text { standard }^{2}\end{array}$ \\
\hline Fat $(\% \mathrm{wt} / \mathrm{wt})$ & 19.9 & 0.6 & - \\
Moisture (\% wt/wt) & 56.9 & 0.7 & $\leq 60$ \\
Protein (\% wt/wt) & 20.6 & 0.8 & - \\
Ca (mg/100 g of cheese) & 428 & 4 & - \\
Na (mg/100 g of cheese) & 13.2 & 0.9 & - \\
Fat in DM (\%) & 46.3 & 1.3 & $\geq 40$ \\
\hline
\end{tabular}

${ }^{1}$ Standard deviation related to 2 replicates of cheese trials.

${ }^{2}$ For salt-brined cheeses (Codex Alimentarius, 2003). 

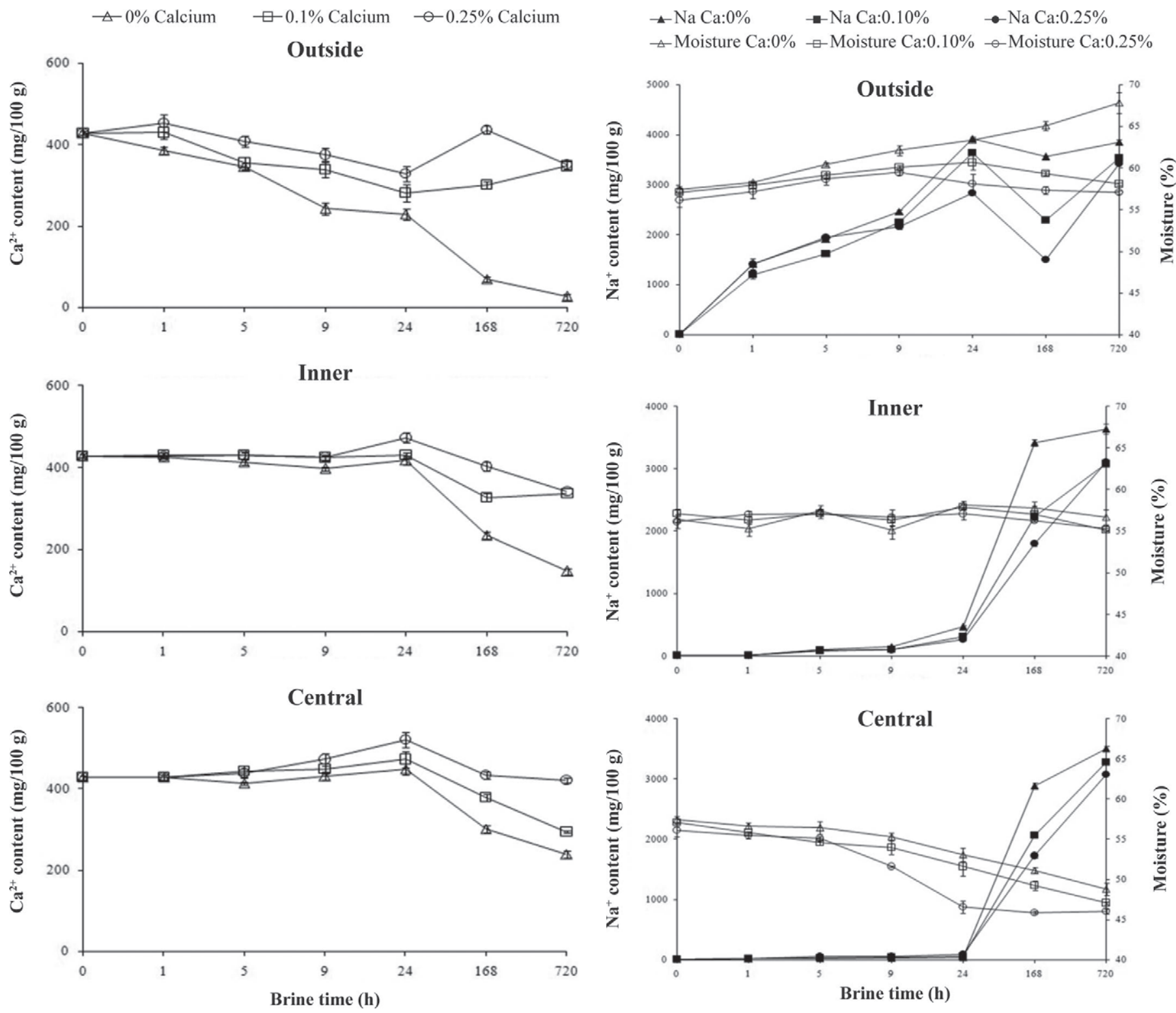

Figure 2. Effect of calcium in brine on calcium content in different regions of Mozzarella cheese during brining. Outside $=0.5$-cm-thick outer surface of the cheese samples; Inner $=$ the region 1 to $1.5 \mathrm{~cm}$ nearer the center of the cheese samples; Central $=$ the region within the inside region of the cheese samples.

Figure 3. Effect of calcium in brine on ionic sodium content and moisture in different regions of Mozzarella cheese during brining. Outside $=0.5-\mathrm{cm}$-thick outer surface of the cheese samples; Inner $=$ the region 1 to $1.5 \mathrm{~cm}$ nearer the center of the cheese samples; Central $=$ the region within the inside region of the cheese samples.

$0,0.10$, and $0.25 \%$ calcium, respectively. These results confirm that calcium can effectively modify the soft and wet surfaces of cheese.

The sodium content of Mozzarella cheese differed with region of the cheese and brining time. The quantity of salt absorbed increased with brining time (Figure 3), albeit at an ever-diminishing rate, as the sodium chloride concentration gradient between the cheese and the brine decreased. Concentration profiles of ionic sodium were superimposed on migration time, in accordance

with earlier studies (Guinee, 2004), implying that the amount of ionic salt taken up by the cheese is proportional to the brining time. Moreover, we observed a large decrease in the salt gradient from the surface to the center of the cheese at the end of brining (Figure 3 ) because of the complex structure of cheese. Movement of ions from high concentrations in the brine to low concentrations within the cheese is impeded by the presence of fat globules and protein aggregates (Floury et al., 2009). 


\section{Salt Effective Diffusion Coefficient Value}

Diffusion properties of cheese solutes depend on (1) their physicochemical characteristics, and (2) the composition and microstructure of the matrix (Floury et al., 2010). The diffusion coefficient represents the apparent diffusivity of sodium chloride, considering the solid cheese matrix and sodium chloride as the 2 components of the binary diffusion system. The effective diffusion coefficient of sodium chloride considers the binary diffusion system constituted by the water in cheese and the sodium chloride solute, which is more representative than the diffusion coefficient (Turhan, 1992; Payne and Morison, 1999).

The results in Table 2 indicate that the effective diffusion coefficient value of sodium decreased during the first $24 \mathrm{~h}$ of brining, and the sodium chloride concentration gradient between the cheese and the brine also decreased. When the brining time was $>24 \mathrm{~h}$, the effective diffusion coefficient fluctuated throughout brining (Table 2). In the present study, salt equilibrium was almost attained after $30 \mathrm{~d}$ of brining (Table 2), and the diffusion of salt changed with chemical and textural characteristics of the cheese, which is in accord with earlier studies (Guinee and Fox, 1983; Morris et al., 1985). Pools of whey are interspersed throughout the cheese and, along with thick strands of protein, make up a continuous network that contains fat globules (McMahon et al., 2009). Therefore, the effective diffusion coefficient value of salt differs from the outer surface of the cheese to the inner portion and with brining time.

The effective diffusion coefficient value of sodium increased with the addition of calcium to the brine (Table 2 ), which implies that the total quantity of sodium absorbed by the cheese decreases. This finding demonstrates that migration of calcium affects diffusion of ionic sodium. The result is in agreement with the report of Guerts et al. (1972), which indicates that cheese salted in calcium-free brine absorbs a larger amount of salt because, in that case, the moisture content in the rind is highest, the rind being the region of highest salt concentration. The mechanism could be related to tightening of the matrix microstructure caused by calcium in the brine. The diffusion of salt would be hindered by a limiting friction effect with a more compact and firmer microstructure of the cheese matrix if water content were low. This hypothesis is in agreement with the results shown in Figure 3, confirming that cheese has a lower water content associated with addition of calcium to the brine. Our results are somewhat different from those reported by Floury et al. (2009), who considered that the calcium content of the cheese was relatively constant over time and with distance from the surface. Rather, our results (Figure 2) indicated

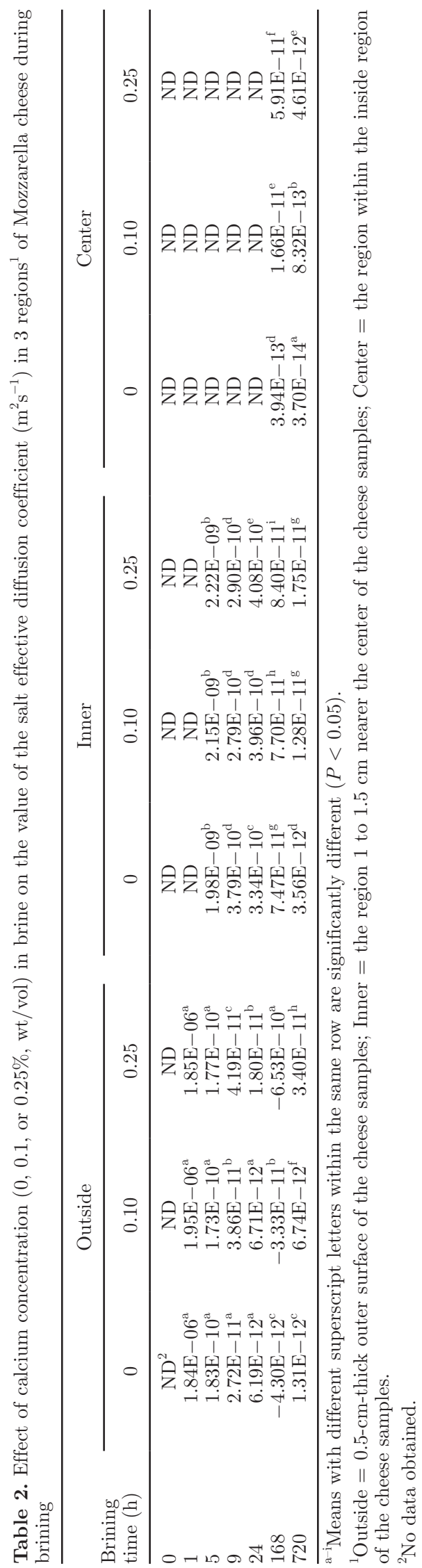


that calcium content was a function of brining time. All calcium was lost, both dissolved and undissolved. Moreover, with increasing addition of calcium, the total uptake of sodium decreased and thus the effective diffusion coefficient value of salt was increased (Table 2 ). These different conclusions could be due to the difference in brine concentration. The study of Floury et al. (2009) was aimed at formulating an artificial saliva solution and the concentration of sodium chloride was about $0.88 \mathrm{~g} / \mathrm{L}$, whereas we chose a sodium chloride concentration of $20 \%$ (wt/vol) for the brine solution. Details of the underlying mechanism need further study but it is undeniable that the calcium content in the cheese changes during brining, which affects the diffusion of salt during brining.

The mechanisms underlying sodium diffusion within cheese during brining are often described by using Fick's second diffusion law, considering the diffusion coefficient as a constant (Luna and Bressan, 1987). However, as shown in this study, the effective diffusion coefficient of sodium is not constant but changes with cheese and brine conditions, as well as time.

\section{Relaxation Time Measurements}

Relaxation time and the corresponding values for the 2 components of signal transverse magnetization in Mozzarella cheese are given in Table 3. Water relaxation is affected by the structure of the cheese network as a result of water-protein interactions. Water translation and the rotation of molecules as well as the chemical exchange process between water molecules and biopolymers or other solutes can be estimated as $T_{2}$ values. Two components for transverse relaxation time have been found in Mozzarella cheese (Godefroy and Callaghan, 2003; Kuo et al., 2003). Components with shorter and longer relaxation times are attributed to the protons in less and more mobile fractions of water in cheese, respectively. Therefore, $T_{21}$ with a relaxation time of 0.1 to $1.95 \mathrm{~ms}$ was the fast relaxation component and was estimated to be roughly $10 \%$ of the water in the cheese (Table 3). These proportions are similar to those reported by Geurts et al. (1974). Bound water is not available to act as a solvent and transmission medium for salt penetration during brining. The relaxation time of $T_{22}$ was between 5.95 and $512.48 \mathrm{~ms}$ and comprised approximately $90 \%$ of the water in cheese.

\section{Proportion of Transversal Relaxation Time}

According to data from the transverse relaxation curve, the effect of calcium in brine on the proportion of $T_{2}$ in different regions of Mozzarella cheese during brining is shown in Figure 4. The shift in distribution and the increment in the population of the component $T_{21}$ were observed as a result of diffusion of salt into the cheese during brining. The increase in casein hydration could be attributed to the binding of ionic sodium by casein and the displacement of calcium or colloidal calcium phosphate from paracasein (Guinee, 2004). Indeed, an inverse relationship between casein hydration and casein-bound calcium in model systems has been reported by several investigators (Guillaume et al., 2002; Guinee et al., 2002; Pastorino et al., 2003). When more calcium becomes soluble, the casein-bound calcium in the cheese solubilizes and restores the equilibrium between the soluble and colloidal forms. Consequently, the reduction in the casein-bound calcium enables paracasein to bind water (McSweeney, 2007).

Figure $3 \mathrm{~A}$ shows that the concentration of calcium in brine had a significant effect on the distribution of water in the outside region of the cheese. Bound water in cheese was significantly lower for the cheese in the brine with added calcium than in cheese in the calcium-free brine. At the end of brining, the amount of water bound to the protein of the cheese increased significantly. Addition of calcium to a final concentration of $0.25 \%$ diminished the proportion of bound water by $20.96 \%$. Like that in the outside region, bound water decreased in the inner and central regions, but the change was not significant. The degree of swelling and the moisture content of the cheese were lower when the solution contained more calcium. The mechanism can be interpreted as follows: the supply of adequate calcium restores the equilibrium between soluble and colloidal forms, preventing paracasein from binding water. Addition of calcium strengthens the interactions between casein micelles and weakens the hydration of the protein. Less hydrated casein results in less solubilization of proteins, strengthening the interaction between them, giving rise to a compact and firmer microstructure of cheese and hindering diffusion of the solutes. Floury et al. (2010) reported that modification of the amount of proteinbound water could result in expansion of the relative pore width of the protein matrix.

Soft or fresh cheeses like Mozzarella contain more water than semi-hard and hard cheeses. Therefore, it is important that the sources, populations, and movement of water are recognized to understand the potential

Table 3. Transversal relaxation time $\left(T_{2}\right)$ and the corresponding proportion values for 2 components of signal transverse magnetization decrease in Mozzarella cheese

\begin{tabular}{lcc}
\hline Component $^{1}$ & $\begin{array}{c}\text { Relaxation } \\
\text { time }(\mathrm{ms})\end{array}$ & $\begin{array}{c}\text { Proportion } \\
(\%)\end{array}$ \\
\hline$T_{21}$ & $0.1-1.95$ & $6-10$ \\
$T_{22}$ & $5.95-512.48$ & $88-92$ \\
\hline${ }^{1} T_{21}=$ bound water; $T_{22}=$ bulk water. &
\end{tabular}




$$
\triangle 0 \% \text { Calcium } \quad \square 0.1 \% \text { Calcium } \quad-0.25 \% \text { Calcium }
$$

A

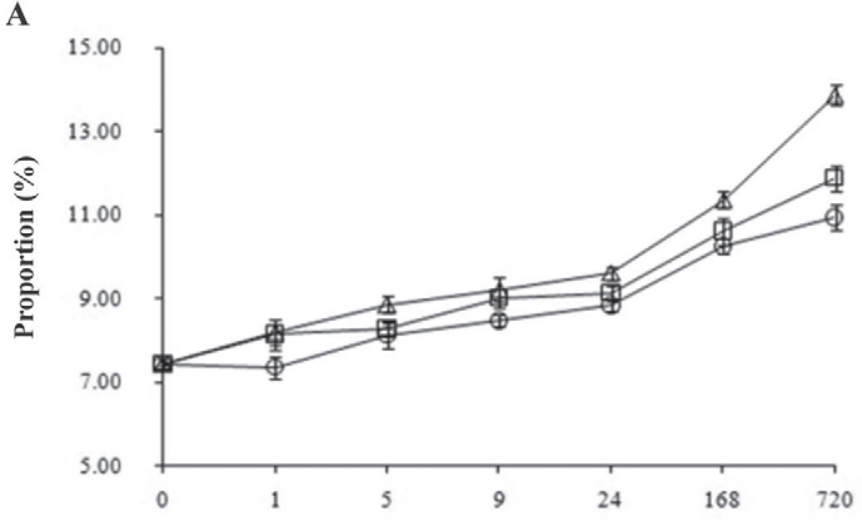

C

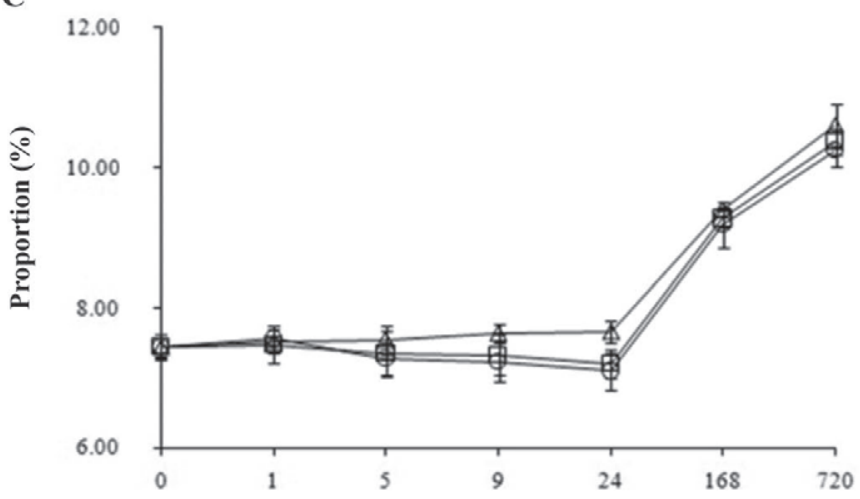

E

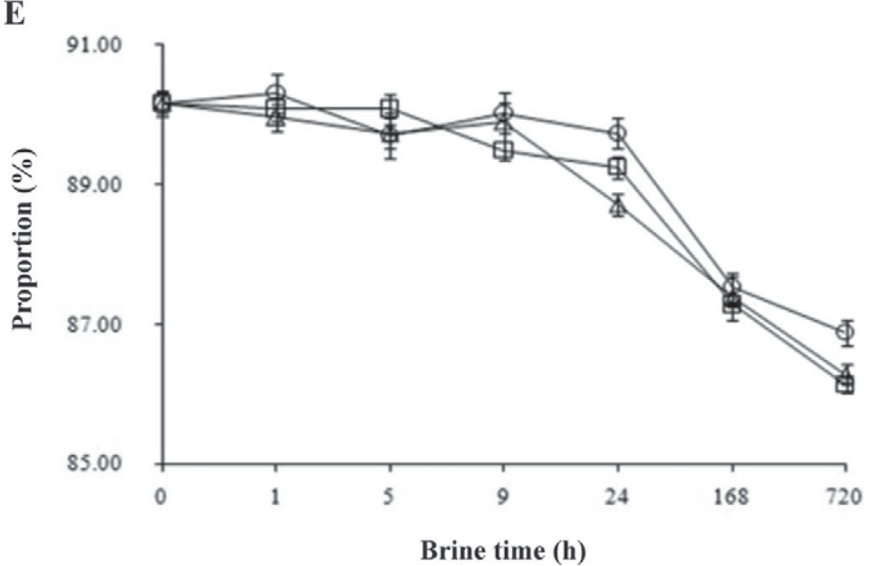

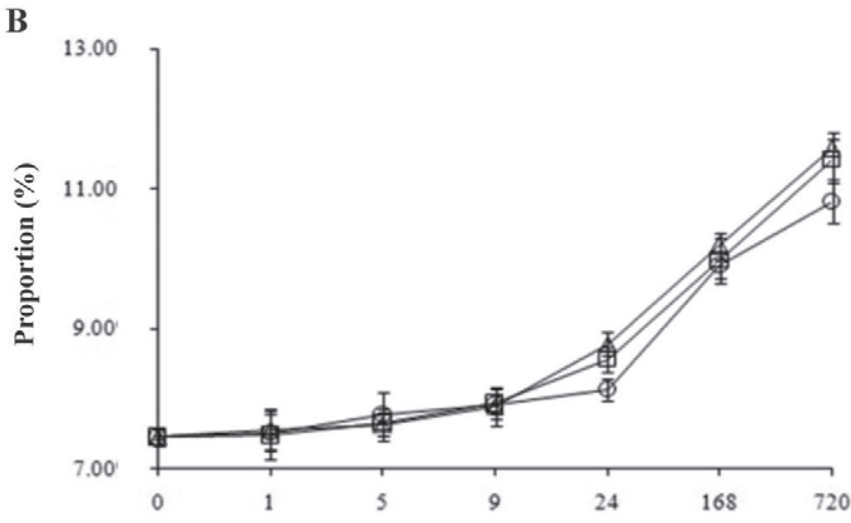

D
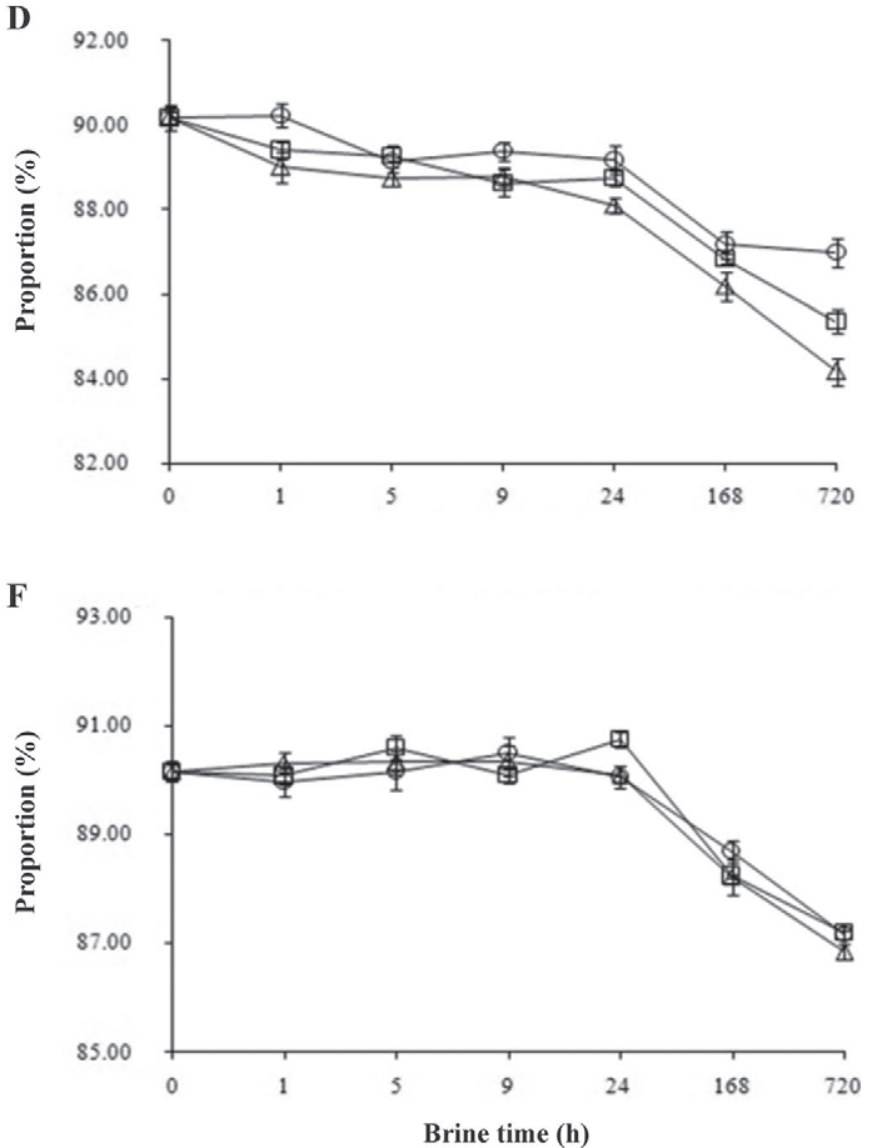

Figure 4. Effect of calcium in brine on the proportions of $T_{21}$ (bound water) and $T_{22}$ (bulk water), respectively, in the outside (A and $\mathrm{D}$ ), inner (B and $\mathrm{E})$, and central $(\mathrm{C}$ and $\mathrm{F}$ ) regions of Mozzarella cheese during brining.

links between brining conditions and the distribution of water within the cheese.

\section{CONCLUSIONS}

This study provides, for the first time, a detailed description of the effects of calcium in brine on Moz- zarella cheese. Calcium in brine affects salt diffusion and the distribution of water in the cheese. Addition of calcium to the brine can lessen the decrease of calcium in the cheese and hinder the diffusion rate of salt. Moreover, by restoring the equilibrium between soluble and colloidal forms of calcium, calcium in brine prevents paracasein from binding water, decreases the 
amount of bound water in cheese, and reduces the risk of the soft rind defect.

\section{ACKNOWLEDGMENTS}

This work was financially supported by the Ministry of Science and Technology of China (2012BAD12B08, 2012BAD28B07) Beijing Science and Technology Project (D101105046010001).

\section{REFERENCES}

AOAC International. 2000. Official Methods of Analysis. Vol. II. 17th ed. AOAC International, Gaithersburg, MD.

Carr, H. Y., and E. M. Purcell. 1954. Effects of diffusion on free precession in nuclear magnetic resonance experiments. Am. J. Physiol. 94:630-638.

Codex Alimentarius. 2003. Codex group standard for cheeses in brine. Codex Standard 208-1999. Adopted in 1999; amendments 2001, 2010. http://www.codexalimentarius.net/web/standard_list.jsp.

Floury, J., S. Jeanson, S. Aly, and S. Lortal. 2010. Determination of the diffusion coefficients of small solutes in cheese: A review. Dairy Sci. Technol. 90:477-508.

Floury, J., O. Rouaud, M. Le Poullennec, and M. H. Famelarta. 2009. Reducing salt level in food: Part 2. Modelling salt diffusion in model cheese systems with regards to their composition. Lebenson. Wiss. Technol. 42:1621-1628.

Gerla, P. E., and A. C. Rubiolo. 2003. A model for determination of multicomponent diffusion coefficients in foods. J. Food Eng. 56:401-410.

Geurts, T. J., P. Walstra, and H. Mulder. 1972. Brine composition and the prevention of the defect 'soft rind' in cheese. Neth. Milk Dairy J. 26:168-179.

Geurts, T. J., P. Walstra, and H. Mulder. 1974. Transport of salt and water during salting of cheese. 1. Analysis of the processes involved. Neth. Milk Dairy J. 28:102-129.

Geurts, T. J., P. Walstra, and H. Mulder. 1980. Transport of salt and water during salting of cheese. 2. Quantities of salt taken up and of moisture lost. Neth. Milk Dairy J. 34:229-254.

Godefroy, S., and P. T. Callaghan. 2003. 2D relaxation/diffusion correlations in porous media. Magn. Reson. Imaging 21:381-383.

Guillaume, C., S. Marchesseau, A. Lagaude, and J. L. Cuq. 2002. Effect of salt addition on the micellar composition of milk subjected to $\mathrm{pH}$ reversible $\mathrm{CO}_{2}$ acidification. J. Dairy Sci. 85:2098-2105.

Guinee, T. P. 2004. Salting and the role of salt in cheese. Int. J. Dairy Technol. 57:99-109.

Guinee, T. P., E. P. Feeney, M. A. E. Auty, and P. F. Fox. 2002. Effect of $\mathrm{pH}$ and calcium concentration on some textural and functional properties of Mozzarella cheese. J. Dairy Sci. 85:1655-1669.

Guinee, T. P., and P. F. Fox. 1983. Sodium chloride and moisture changes in Romano-type cheese during salting. J. Dairy Res. 50:511-518.
Guinee, T. P., and P. F. Fox. 1986. Influence of cheese geometry on the movement of sodium chloride and water during brining. Irish J. Food Sci. Technol. 10:73-96.

ISO-IDF. 1982. Cheese and processed cheese: Determination of total solids content of cheese and processed cheese. Standard 4A. International Dairy Federation, Brussels, Belgium.

ISO-IDF. 1986. Determination of nitrogen content (Kjeldahl method) and calculation of crude protein content. Standard 20A. International Dairy Federation, Brussels, Belgium.

Kindstedt, P. S. 1991. Controlling the physical properties of Mozzarella cheese. Seminar. Center for Dairy Research. University of Wisconsin, Madison.

Kindstedt, P. S. 1994. Factors that influence the shredding characteristics of Mozzarella cheese. Proc. 3rd. California Cheese Symp. Univ. California, Davis.

Kindstedt, P. S., K. L. Larose, J. A. Gilmore, and L. Davis. 1996. Distribution of salt and moisture in Mozzarella cheese with soft surface defect. J. Dairy Sci. 79:2278-2283.

Kristensen, J. M. B. 1999. Salting of the cheese. Chapter 11 in Cheese Technology - A Northern European Approach. Int. Dairy Books, Aarhus, Denmark.

Kuo, M. I., M. E. Anderson, and S. Gunasekaran. 2003. Determining effects of freezing on pasta filata and non-pasta filata Mozzarella cheeses by nuclear magnetic resonance imaging. J. Dairy Sci. 86:2525-2536.

Luna, J. A., and J. A. Bressan. 1987. Mass transfer during ripening of Cuartirolo Argentino cheese. J. Food Sci. 52:308-311.

Marshall, R. T. 1992. Standard Methods for the Examination of Dairy Products. 16th ed. American Public Health Association, Washington, DC

McMahon, D. J., R. L. Fife, and C. J. Oberg. 1999. Water partitioning in Mozzarella cheese and its relationship to cheese meltability. J. Dairy Sci. 82:1361-1369.

McMahon, D. J., M. M. Motawee, and W. R. McManus. 2009. Influence of brine concentration and temperature on composition, microstructure, and yield of feta cheese. J. Dairy Sci. 92:4169-4179.

McSweeney, P. L. H. 2007. Cheese Problems Solved. CRC Press, Washington, DC

Morris, H. A., T. P. Guinee, and P. F. Fox. 1985. Salt diffusion in Cheddar cheese. J. Dairy Sci. 68:1851-1858.

Pajonk, A. S., R. Saurel, and J. Andrieu. 2003. Experimental study and modeling of effective $\mathrm{NaCl}$ diffusion coefficients values during Emmental cheese brining. J. Food Eng. 60:307-313.

Pastorino, A. J., N. P. Ricks, C. L. Hansen, and D. J. McMahon. 2003. Effect of calcium and water injection on structure-function relationships of cheese. J. Dairy Sci. 86:105-113.

Payne, M. R., and K. R. Morison. 1999. A multi-component approach to salt and water diffusion in cheese. Int. Dairy J. 9:887-894.

Pedersen, H. T., R. Bro, and S. B. Engelsen. 2002. Towards rapid and unique curve resolution of low-field NMR relaxation data: Trilinear SLICING versus two dimensional curve fitting. J. Magn. Reson. 157:141-155.

Turhan, M., and G. Kaletunç. 1992. Modelling of salt diffusion in white cheese during long-term brining. J. Food Sci. 57:1082-1085. 